Article

\title{
Comparison of Hook and Straight Steel Fibers Addition on Malaysian Fly Ash-Based Geopolymer Concrete on the Slump, Density, Water Absorption and Mechanical Properties
}

\author{
Meor Ahmad Faris 1,2,*, Mohd Mustafa Al Bakri Abdullah 2,3,*, Ratnasamy Muniandy 4 , \\ Mohammad Firdaus Abu Hashim ${ }^{1,2}$, Katarzyna Błoch ${ }^{5}$ D , Bartłomiej Jeż ${ }^{5}$, Sebastian Garus ${ }^{6}(\mathbb{D}$, \\ Paweł Palutkiewicz ${ }^{6}$ (D), Nurul Aida Mohd Mortar ${ }^{2,3}$ and Mohd Fathullah Ghazali ${ }^{1,2}$ (D)
}

1 Faculty of Mechanical Engineering Technology, University Malaysia Perlis (UniMAP), Arau 02600, Perlis, Malaysia; firdaushashim@unimap.edu.my (M.F.A.H.); fathullah@unimap.edu.my (M.F.G.)

2 Center of Excellence Geopolymer and Green Technology (CEGeoGTech), Universiti Malaysia Perlis (UniMAP), Kangar 01000, Perlis, Malaysia; nurulaida@unimap.edu.my

3 Faculty of Chemical Engineering Technology, University Malaysia Perlis (UniMAP), Arau 02600, Perlis, Malaysia

4 Department of Civil Engineering, University Putra Malaysia, Serdang 43400, Selangor, Malaysia; ratnas@eng.upm.edu.my

check for updates

Citation: Faris, M.A.; Abdullah, M.M.A.B.; Muniandy, R.; Abu Hashim, M.F.; Błoch, K.; Jeż, B.; Garus, S.; Palutkiewicz, P.; Mohd Mortar, N.A.; Ghazali, M.F. Comparison of Hook and Straight Steel Fibers Addition on Malaysian Fly Ash-Based Geopolymer Concrete on the Slump, Density, Water Absorption and Mechanical Properties. Materials 2021, 14, 1310. https://doi.org/10.3390/ma14051310

Academic Editor: Dolores Eliche Quesada

Received: 3 February 2021

Accepted: 5 March 2021

Published: 9 March 2021

Publisher's Note: MDPI stays neutral with regard to jurisdictional claims in published maps and institutional affiliations.

Copyright: (c) 2021 by the authors. Licensee MDPI, Basel, Switzerland. This article is an open access article distributed under the terms and conditions of the Creative Commons Attribution (CC BY) license (https:/ / creativecommons.org/licenses/by/ $4.0 /)$.
5 Department of Physics, Częstochowa University of Technology, 42-200 Częstochowa, Poland; katarzyna.bloch@pcz.pl (K.B.); bartek199.91@o2.pl (B.J.)

6 Faculty of Mechanical Engineering and Computer Science, Częstochowa University of Technology, 42-200 Częstochowa, Poland; gari.sg@gmail.com (S.G.); palutkiewicz@ipp.pcz.pl (P.P.)

* Correspondence: meorfaris@unimap.edu.my (M.A.F.); mustafa_albakri@unimap.edu.my (M.M.A.B.A.)

\begin{abstract}
Geopolymer concrete has the potential to replace ordinary Portland cement which can reduce carbon dioxide emission to the environment. The addition of different amounts of steel fibers, as well as different types of end-shape fibers, could alter the performance of geopolymer concrete. The source of aluminosilicate (fly ash) used in the production of geopolymer concrete may lead to a different result. This study focuses on the comparison between Malaysian fly ash geopolymer concrete with the addition of hooked steel fibers and geopolymer concrete with the addition of straight-end steel fibers to the physical and mechanical properties. Malaysian fly ash was first characterized by X-ray fluorescence (XRF) to identify the chemical composition. The sample of steel fiber reinforced geopolymer concrete was produced by mixing fly ash, alkali activators, aggregates, and specific amounts of hook or straight steel fibers. The steel fibers addition for both types of fibers are $0 \%, 0.5 \%$, $1.0 \%, 1.5 \%$, and $2.0 \%$ by volume percentage. The samples were cured at room temperature. The physical properties (slump, density, and water absorption) of reinforced geopolymer concrete were studied. Meanwhile, a mechanical performance which is compressive, as well as the flexural strength was studied. The results show that the pattern in physical properties of geopolymer concrete for both types of fibers addition is almost similar where the slump is decreased with density and water absorption is increased with the increasing amount of fibers addition. However, the addition of hook steel fiber to the geopolymer concrete produced a lower slump than the addition of straight steel fibers. Meanwhile, the addition of hook steel fiber to the geopolymer concrete shows a higher density and water absorption compared to the sample with the addition of straight steel fibers. However, the difference is not significant. Besides, samples with the addition of hook steel fibers give better performance for compressive and flexural strength compared to the samples with the addition of straight steel fibers where the highest is at $1.0 \%$ of fibers addition.
\end{abstract}

Keywords: geopolymer; alkali activated material; reinforced concrete; steel fiber; physical properties; mechanical properties; flexural 


\section{Introduction}

Currently, geopolymer concrete has emerged in the last two decades as new engineering materials with the potential of becoming a significant element in the environmentally sustainable construction and construction industry [1]. The reaction of aluminosilicatecontaining fly ash with alkali produces an inorganic polymer binder, which is called geopolymer. A concrete geopolymer was studied by several researchers [2-5]. Geopolymer was also developed for other applications including lightweight concrete [6], material for computer numerical control (CNC) cutting tools [7-10], piping materials [11], and water treatment [12].

Based on previous research, the interfacial bonding carried out using the pull-out test have shown that Ordinary Portland Cement (OPC) mortars are generally excellent [13]. Recently, the works related to steel reinforcing fiber on Ordinary Portland Cement (OPC) composite, including fly ash, rice hush-bark, and silica fume have been studied. The results indicated that the OPC composite bonding strength was improved on the aging of the 28th day [14].

Hooked steel fiber is widely used for OPC concrete reinforcement [15-17]. The material properties of fibers are usually more dominant in affecting the performance of a reinforced geopolymer composite than binders [18]. The role of the fiber is very important as it is mainly reflected when the concrete starts to crack and it also improves the post-cracking performance as there is the fiber bridging of the crack section. It is said that adding steel fibers to concrete can produce a better crack control effect and improve the tensile strength before and after cracking initiates [19-21]. The inclusion of steel fibers could help to improve fatigue strength and dynamic resistance of the concrete. However, as the amount of steel fiber added increases, the workability of concrete will decrease [21].

Concrete geopolymer has excellent strength without any fiber reinforcement $[1,22]$ and good fire resistance. Fibers are incorporated into OPC concrete to overcome this weakness, producing materials with increased tensile strength, ductility, toughness, and increased durability properties. Fiber efficiency in the concrete mixture depends on factors such as fiber matrix properties, the volume of fiber inclusion, fiber geometry, the types of fiber, as well as fiber orientation. To improve durability, strength, and different properties of hardened concrete, a wide range of fibers must be studied. Most of the fibers are made of steel, carbon, or polymer [23]. The selection of steel fiber is chosen for this research to gather the data of strength, and different properties on geopolymer concrete.

Research on the addition of steel fibers in OPC concrete to enhance the performance has been extensively studied by many researchers [24-26] over the world but is quite limited to fly ash-based geopolymer concrete. In the production of geopolymer concrete, the chemical composition of raw material, which is fly ash, is not standardized, especially as it comes from different sources. The different chemical content of fly ash may influence to the different properties and performance of geopolymer concrete. Besides, the study on mechanical and physical properties of fly ash-based geopolymer concrete with the reinforcement of steel fibers is limited. This paper aims to study the effects of steel fibers as an addition to the physical and mechanical properties of Malaysian fly ash-based geopolymer concrete.

\section{Materials and Methodology}

\subsection{Preparation of SFRGC}

Steel Fiber Reinforcement Geopolymer Concrete (SFRGC) is mixing between geopolymer binder which is fly ash, an alkali activator, aggregates, and a specific amount of steel fibers. Firstly, an alkali activator was produced by mixing sodium silicate $\left(\mathrm{Na}_{2} \mathrm{SiO}_{3}\right)$ and sodium hydroxide $(\mathrm{NaOH})$ at a ratio equal to 2.5. The $\mathrm{Na}_{2} \mathrm{SiO}_{3}$ was from South Pacific Chemicals Industry Sdn. Bhd. (SPCI), Penang, Malaysia with a ratio of $\mathrm{SiO}$ and $\mathrm{Na}_{2} \mathrm{O}$ equal to 3.2. $\mathrm{NaOH}$ is in a form of a pallet that was bought from Farmosa Plastic Corporation, Kaohsiung, Taiwan. The $\mathrm{NaOH}$ pellet was first diluted in distilled water and as a result, a concentration of $12 \mathrm{M}$ was produced. 
Fly ash was taken from the electric power plant Manjung, Perak, Malaysia. Aggregates, which are river sand and granite, were used at a maximum size equal to $4.75 \mathrm{~mm}$ and $20 \mathrm{~mm}$ respectively. The ratio of fly ash to alkali activators is equal to 2 . The steel fibers used in this experiment are hook and straight end as shown in Figure 1. The percentage of steel fibers as an addition in the geopolymer concrete mixture has been set based on the volume fraction of samples which are $0 \%, 0.5 \%, 1.0 \%, 1.5 \%$, and $2.0 \%$. The details mix proportion of the SFRGC is tabulated in Table 1 . Besides, the details of the end-shape steel fibers specification used in the production of SFRGC was summarized in Table 2 as hook steel fiber and in Table 3 as straight steel fiber.

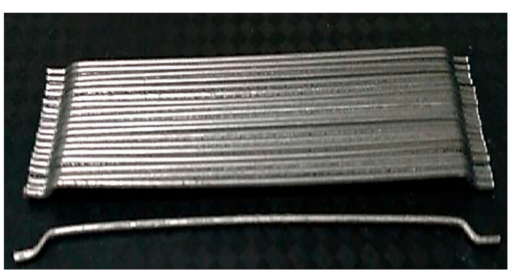

(a)

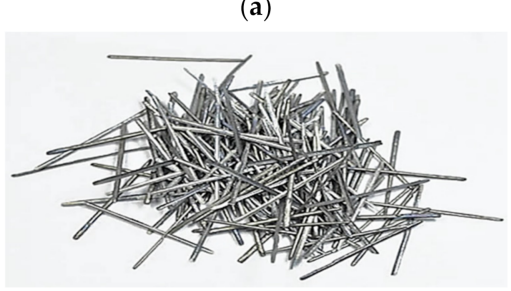

(b)

Figure 1. Steel fibers: (a) Hook fibers and (b) straight fibers.

Table 1. Mix design of steel fiber reinforced geopolymer concrete.

\begin{tabular}{|c|c|c|c|c|c|}
\hline $\begin{array}{c}\text { Steel Fibers } \\
\text { Addition (\%) }\end{array}$ & $\begin{array}{l}\text { Fly Ash } \\
\left(\mathrm{kg} / \mathrm{m}^{3}\right)\end{array}$ & $\begin{array}{c}\text { Coarse } \\
\text { Aggregate } \\
\left(\mathrm{kg} / \mathrm{m}^{3}\right)\end{array}$ & $\begin{array}{c}\text { Fine } \\
\text { Aggregate } \\
\left(\mathrm{kg} / \mathrm{m}^{3}\right)\end{array}$ & $\begin{array}{l}\text { Sodium } \\
\text { Silicate } \\
\left(\mathrm{kg} / \mathrm{m}^{3}\right)\end{array}$ & $\begin{array}{c}\text { Sodium } \\
\text { Hydroxide } \\
\left(\mathrm{kg} / \mathrm{m}^{3}\right)\end{array}$ \\
\hline 0 & 640 & 864 & 576 & 229 & 91 \\
\hline 0.5 & 630.44 & 851.10 & 567.40 & 225.58 & 89.42 \\
\hline 1.0 & 620.99 & 838.34 & 558.89 & 222.20 & 88.30 \\
\hline 1.5 & 611.63 & 825.70 & 550.47 & 218.85 & 86.97 \\
\hline 2.0 & 602.36 & 813.19 & 542.13 & 215.53 & 85.65 \\
\hline
\end{tabular}

Table 2. Specifications of hooked steel fibers.

\begin{tabular}{cc}
\hline Items & Specifications \\
\hline Fiber type & Hooked \\
Diameter $(\mathrm{mm})$ & 0.60 \\
Length $(\mathrm{mm})$ & 0.75 \\
Aspect ratio & 80 \\
\hline
\end{tabular}

Table 3. Specifications of straight steel fibers.

\begin{tabular}{cc}
\hline Items & Specifications \\
\hline Fiber type & Straight \\
Diameter $(\mathrm{mm})$ & 0.60 \\
Length $(\mathrm{mm})$ & 0.75 \\
Aspect ratio & 80 \\
\hline
\end{tabular}

The samples of SFRGC were cast in a mold size of $100 \mathrm{~mm} \times 100 \mathrm{~mm} \times 100 \mathrm{~mm}$ for physical (workability, density, and water absorption) and mechanical (compressive 
and flexural) tests. Samples were taken out from the mold after $24 \mathrm{~h}$ and cured at room temperature for 28 days.

\subsection{Slump Test}

Workability of SGRGC was measured by a slump test. The slump test was performed based on ASTM C143 [27]. After the mixing process, the fresh geopolymer concrete was poured into a slump cone in three layers. Each layer was compacted by rodding 25 strokes by suing the tamping rod. The excess of fresh SFRGC was removed by scrapping off from the top of the cone. The slump cone then was immediately removed from the fresh SFRGC by raising it up vertically. The slump was measured by determining the distance between the top of the slump cone and the displaced original center of the top surface of the fresh SFRGC.

\subsection{Density Test}

A density test was conducted after the sample solidified for 28 days. A sample was immersed in water for $24 \mathrm{~h}$ at ambient temperature. The sample of SFRGC was placed separately (no contact) from each other in a water tank. The top of the sample surface was not lower than $150 \mathrm{~mm}$ below the water surface. The immersed sample was placed on a wire mesh to ensure there is a gap between the sample and bottom of the water container at a distance of about $3 \mathrm{~mm}$.

The sample of SFRGC that completely was immersed in water for $24 \mathrm{~h}$ was weighed and recorded as immersed weight (Wi). The sample then was removed from the water tank and allowed to dry for $1 \mathrm{~min}$. Any visible water on the surface of the sample was removed by a damp cloth. Then, the sample was weighed and recorded as saturated weighed (Ws). After that, the sample was dried in an oven at a temperature of $110^{\circ} \mathrm{C}$ for $24 \mathrm{~h}$. Then, the dried sample was weighed and labeled as dried weight $(\mathrm{Wd})$. The detail calculation of density of SFRGC is summarized as in Equation 1:

$$
\text { Density, } \mathrm{D}=\left(\frac{\mathrm{W}_{\mathrm{d}}}{\mathrm{W}_{\mathrm{s}}-\mathrm{W}_{\mathrm{i}}}\right) \times 1000
$$

where:

$\mathrm{W}_{\mathrm{d}}=$ oven dry weight of specimen $(\mathrm{kg})$;

$\mathrm{W}_{\mathrm{s}}=$ saturated weight of specimen $(\mathrm{kg})$;

$\mathrm{W}_{\mathrm{i}}=$ immersed weight of specimen $(\mathrm{kg})$.

\subsection{Water Absorption Test}

Meanwhile, a water absorption test was conducted to determine the moisture content of the samples. The experimental procedure of water absorption was conducted in a similar way to the density test in Section 2.2 but different with the calculation. The water absorption of the SFRGC was measured by Equation (2):

$$
\text { Percentage of water absorption }(\%)=\left(\frac{W_{s}-W_{d}}{W_{d}}\right) \times 100
$$

where:

$\mathrm{W}_{\mathrm{d}}=$ oven dry weight of specimen $(\mathrm{kg})$;

$\mathrm{W}_{\mathrm{s}}=$ saturated weight of specimen $(\mathrm{kg})$;

$\mathrm{W}_{\mathrm{i}}=$ immersed weight of specimen $(\mathrm{kg})$.

\subsection{Compression Test}

The compressive strength of sample SFRGC was measured by following standard BS 1881-116 [28] using Universal Testing Machine (UTM) Automatic Max (Instron, 5569, Norwood, MA, USA). This testing was conducted for sample cured at 28 days in ambient temperature. The load speed was adjusted to $0.1 \mathrm{kN} / \mathrm{s}$. 


\subsection{Flexural Test}

The flexural test, was performed to measure the flexural strength of the sample. The sample was subjected to 4 point bending and tested by using the UTM model Automatic Max (Instron, 5569, Norwood, MA, USA). The testing was conducted by following ASTM C1018 [29]. The constant deflection rate applied in this testing was in the range of $0.05-0.10 \mathrm{~mm} / \mathrm{min}$. The lower and upper support are $300 \mathrm{~mm}$ and $100 \mathrm{~mm}$ respectively. The sample was tested at 28 days after being cured at ambient temperature.

\section{Results and Discussion}

\subsection{Chemical Composition}

The chemical composition of fly ash that has been used in the production of geopolymer concrete for both types of fibers is summarized in Table 4. The total amounts of $\mathrm{SiO}_{2}$ and $\mathrm{Al}_{2} \mathrm{O}_{3}$ are $53.5 \%$ from the total composition. Fly ash used in this experiment fulfils the fundamental as a source of material to be used as a precursor in a geopolymerization process where it is rich in $\mathrm{Si}$ and $\mathrm{Al}$, which will be activated by alkali solution. This fly ash is verified as Class F by ASTM C618 [30]. This verification is based on the chemical content of $\mathrm{CaO}, \mathrm{Al}_{2} \mathrm{O}_{3}, \mathrm{SiO}_{2}$, and $\mathrm{Fe}_{2} \mathrm{O}_{3}$.

Table 4. Chemical composition of fly ash.

\begin{tabular}{cc}
\hline Element & Percentage (\%) \\
\hline $\mathrm{SiO}_{2}$ & 38.80 \\
$\mathrm{Fe}_{2} \mathrm{O}_{3}$ & 19.48 \\
$\mathrm{CaO}$ & 18.10 \\
$\mathrm{Al}_{2} \mathrm{O}_{3}$ & 14.70 \\
$\mathrm{MgO}$ & 3.30 \\
$\mathrm{~K}_{2} \mathrm{O}$ & 1.79 \\
$\mathrm{SO}_{3}$ & 1.50 \\
$\mathrm{MnO}$ & 0.16 \\
$\mathrm{BaO}$ & 0.27 \\
$\mathrm{TiO}_{2}$ & 1.02 \\
\hline
\end{tabular}

\subsection{Slump}

The slump was measured by using a conventional slump cone. The slump test in this research was measured to find consistency and workability of geopolymer concrete between hook steel fiber and straight steel fiber reinforced. Figure 2 showed the decrease trend workability between hook steel fiber and straight steel fiber.

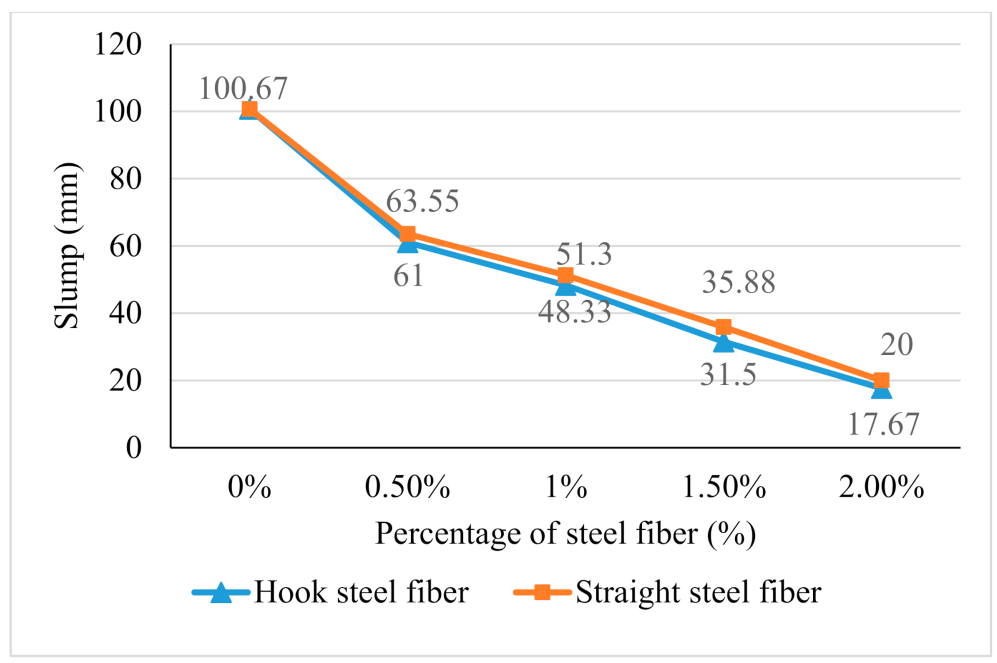

Figure 2. Slump of geopolymer concrete with the addition of hook steel fibers and straight steel fibers. 
Figure 2 illustrates that the slump test result of geopolymer concrete without the addition of steel fibers was $100.67 \mathrm{~mm}$. The slump of geopolymer concrete for hook steel fibers addition decreased with the increasing additions of steel fibers from $0 \%$ to $2 \%$ which are $61 \mathrm{~mm}$ ( $0.5 \%$ steel fibers), $48.33 \mathrm{~mm}$ (1\% steel fibers), $31.5 \mathrm{~mm}$ (1.5\% steel fibers), and $17.67 \mathrm{~mm}$ (2.0\% steel fiber). Meanwhile, the slump of straight steel fiber had also decreased with the increasing addition of steel fibers which is $63.55 \mathrm{~mm}(0.5 \%$ steel fibers), $51.3 \mathrm{~mm}$ ( $1 \%$ steel fibers), $35.88 \mathrm{~mm}$ (1.5\% steel fibers), and $20 \mathrm{~mm}$ ( $2.0 \%$ steel fiber). This has shown that the existence of steel fibers will reduce the workability of geopolymer concrete. The workability of concrete will significantly decrease due to the increase of resistance between the steel fibers and geopolymer matrix called interlocking as shown in Figure 3.

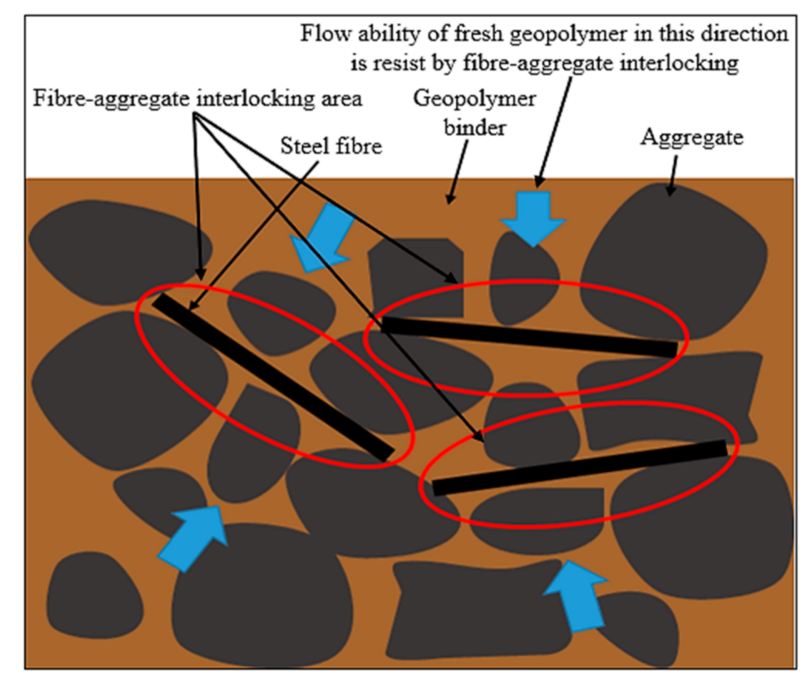

Figure 3. Flow of fresh reinforced geopolymer concrete is resisted by fiber-aggregate interlocking.

Meanwhile, the slump of hook steel fiber was lower than the straight steel fiber due to the function of the hook end that creates higher flow resistance to the fresh geopolymer concrete compared to the geopolymer concrete reinforced with straight steel fiber. The medium value for the slump test of OPC concrete ranges between $50 \mathrm{~mm}$ to $100 \mathrm{~mm}$. Based on this result, it can be concluded that the range of $17.67 \mathrm{~mm}$ to $100 \mathrm{~mm}$ can be considered as low and medium workability. This indicates that the mixing process involved with these materials is suitable to be produced by using a vibrator or manually.

\subsection{Density}

The density of a substance is measured as mass per unit volume. All the samples were measured after being cured for 28 days at room temperature by their mass and divided by the size of mold which is $100 \mathrm{~mm} \times 100 \mathrm{~mm} \times 100 \mathrm{~mm}$. Figure 4 shows the graph comparison of density between hooked steel fiber and straight steel with different fibers addition.

From the results, the density of $2 \%$ steel fiber additions for both hooked and straight steel fiber was the highest with $0.25 \mathrm{~kg} / \mathrm{m}^{3}$ and $0.249 \mathrm{~kg} / \mathrm{m}^{3}$ respectively. The density of geopolymer increased proportionally with the increase of both steel fibers addition. The density of geopolymer concrete with the addition of hook steel fibers seems higher than the density of geopolymer concrete with the addition of straight steel fibers in all percentage of fibers addition. The addition of steel fiber increased the density because of different specific gravity for steel fiber which is $7800 \mathrm{~kg} / \mathrm{m}^{3}$ compared to a normal geopolymer which is $2345 \mathrm{~kg} / \mathrm{m}^{3}$ and it gives an impact for a density value of SFRGC. The increase of concrete density by the addition of aggregate or reinforcement fibers with higher specific gravity was also mentioned by Harshavardhan and Bala Murugan [31]. 


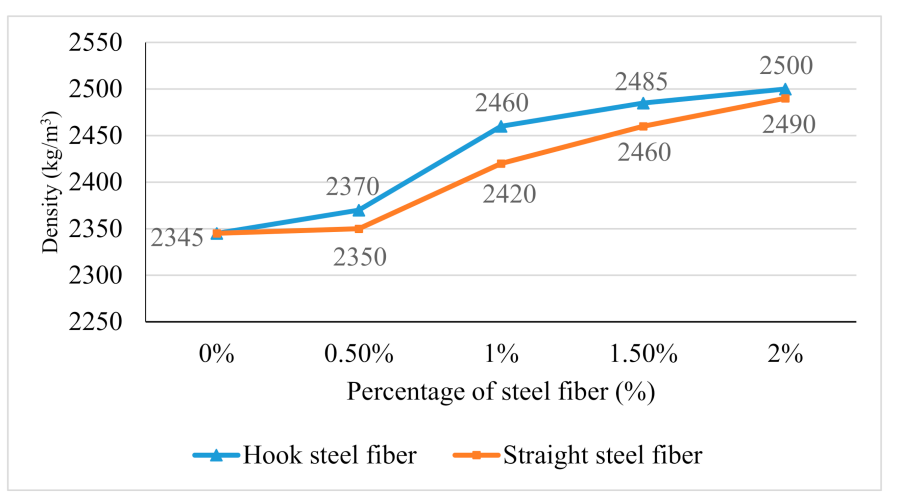

Figure 4. Density of hook and straight steel fiber against steel fibers addition.

\subsection{Water Absorption}

Figure 5 shows the result of the water absorption test. The water absorption of geopolymer concrete was increased with the increase of both types of fiber additions. The highest water absorption for geopolymer concrete with the addition of hook steel fibers and straight steel fibers are $1.35 \%$ and $1.85 \%$ which is $2 \%$ of the steel fibers addition. This is due to the workability which decreased with the addition of steel fibers obtained in this research, which can lead to an increase in pores formation. The water absorption of geopolymer concrete with the addition of hook steel fibers seems higher than the straight steel fiber. This is due to the workability of geopolymer concrete with the addition of hook steel fibers which is lower compared to the geopolymer concrete with the addition of straight steel fibers.

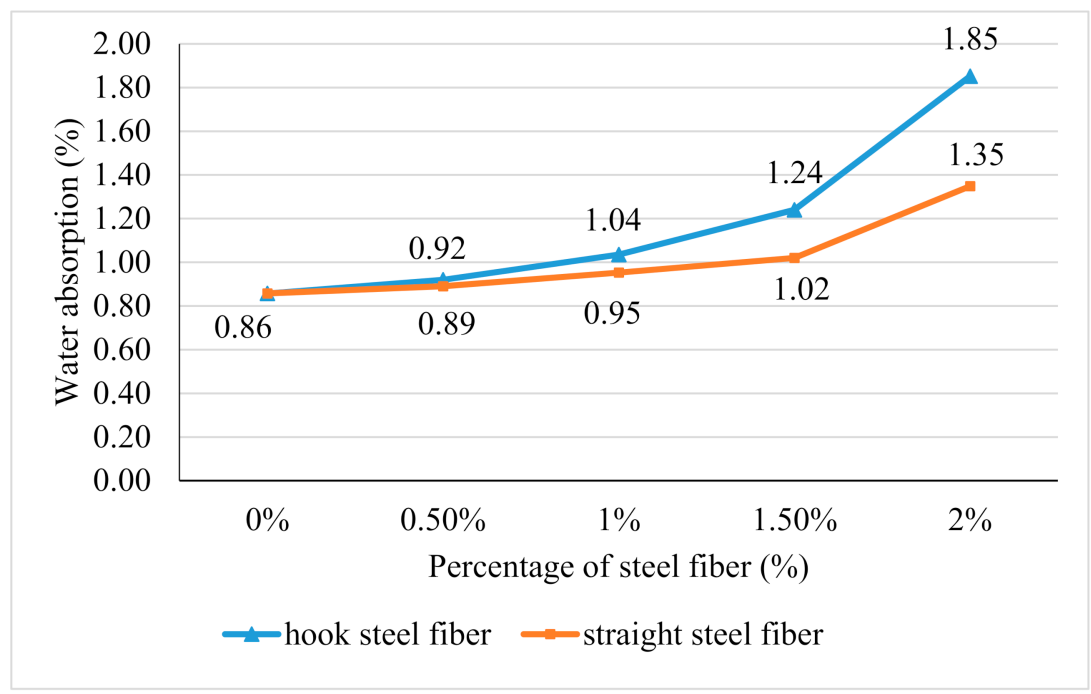

Figure 5. Water absorption of geopolymer concrete with the addition of hooked and straight steel fibers.

\subsection{Compressive Strength}

The compressive strength of steel fiber reinforced geopolymer concrete for both samples are summarized as in Figure 6. The addition of hook steel fibers and straight steel fibers seems to improve the compressive strength of geopolymer concrete until its maximum value at $1 \%$ of fibers addition. This is due to the steel fibers that help to stop the propagation of crack during the compression load. Besides, the compressive strength of hook steel fibers addition seems better than the straight steel fibers addition. This is due to the contribution of the end types of steel fibers in which the anchorage of hook steel fibers will produce higher resistance when slipping out from the geopolymer binder during the cracking compared to the straight steel fibers that do not have anchorage. 


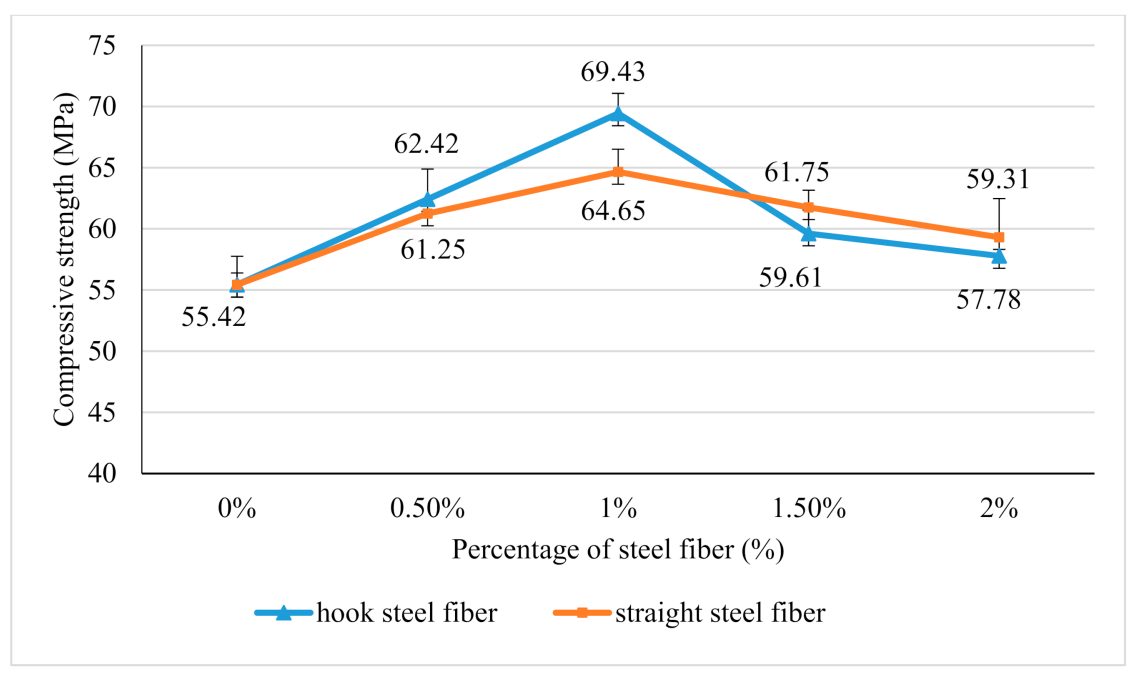

Figure 6. Compressive strength of hook steel fiber and straight steel fiber reinforced geopolymer concrete versus steel fibers addition.

However, the compressive strength of geopolymer concrete decreases as the addition of the fibers exceeds $1.5 \%$. This may be due to the poor workability of geopolymer concrete with the addition of steel fibers starting at $1.5 \%$, which is around $31.5 \mathrm{~mm}$ and $35.88 \mathrm{~mm}$ for the inclusion of hook and straight steel fiber respectively.

\subsection{Flexural Strength}

The effect of steel fibers addition to the flexural strength of geopolymer concrete is summarized in Figure 7. The inclusion of hook steel fibers and straight steel fibers increases the flexural strength of geopolymer concrete until the addition of a maximum fiber at $1.5 \%$ which is $11.12 \mathrm{MPa}$ and $9.42 \mathrm{MPa}$ respectively. The improvement of flexural strength is due to the steel fibers, which functioned to stop the propagation of crack during the flexural testing by creating a bridging at the crack area as shown in Figure 8. The higher the amount of steel fibers, the higher the flexural load that the sample can absorb before completely failing.

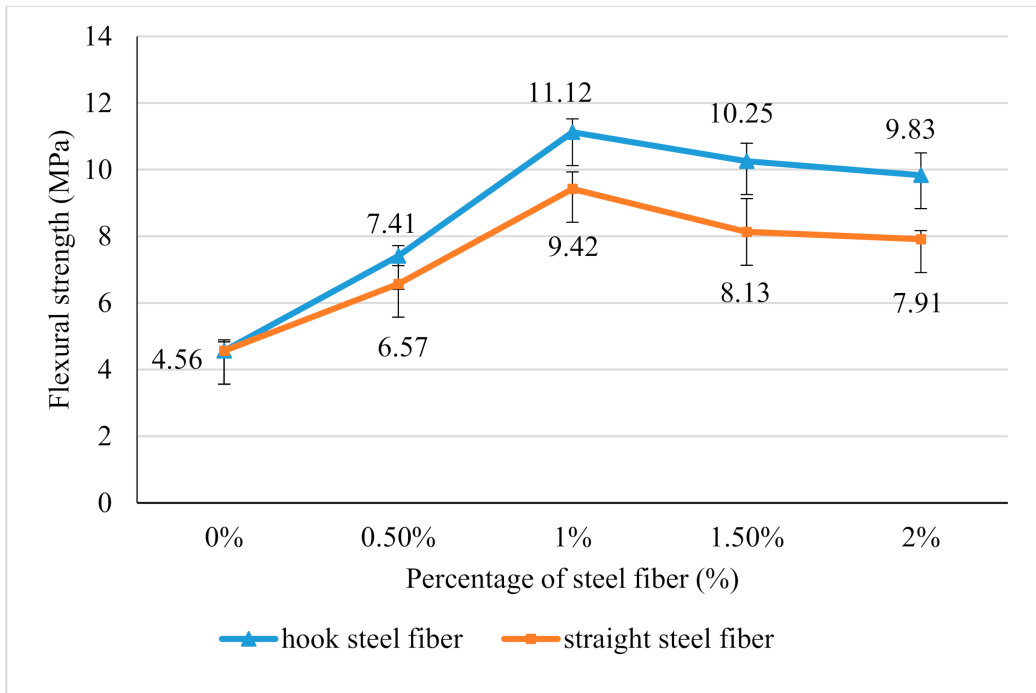

Figure 7. Flexural strength of hook steel fiber and straight steel fiber reinforced geopolymer concrete versus steel fibers addition. 


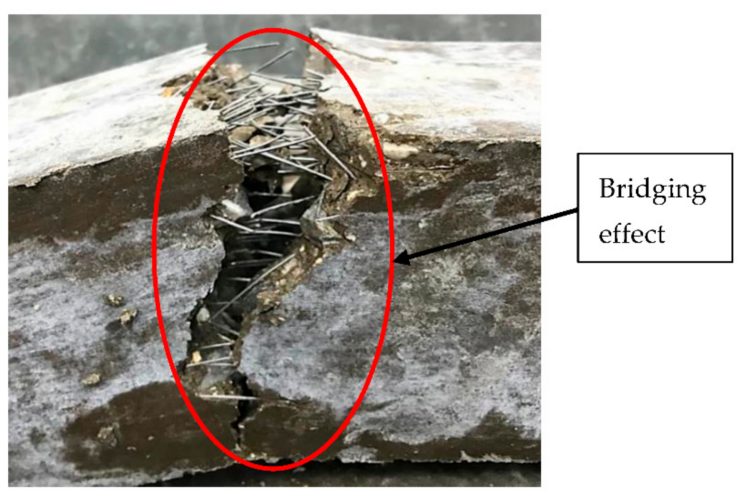

Figure 8. Sample of Steel Fiber Reinforcement Geopolymer Concrete (SFRGC) after a flexural test shows the bridging effect at the cracking area.

However, the performance of flexural drops when the steel fibers addition exceeds $1.5 \%$ for both types of fibers. This is related to the poor workability of samples when steel fibers are added at a high amount. This poor workability may affect the steel fibers dispersion resulting in the steel fibers not being dispersed uniformly. Hence, the absorption capacity inside the sample is imbalance when loading is applied. Therefore, the sample tends to crack at the area that contains fewer fibers.

Besides, the addition of hooked steel fibers shows a higher flexural strength compared to the straight steel fibers at all percentage of steel fibers addition. This is due to the anchorage of hooked steel fibers, which provides extra loading capacities during the flexural test compared to the straight steel fibers. The anchorage of hooked end steel fibers increases the resistance and friction between the fibers and geopolymer matrix when a load is applied. This indicates that higher energy is required to slip out the hooked end steel fibers from the geopolymer matrix.

\section{Conclusions}

The reinforcement of Malaysian fly ash-based geopolymer concrete by the addition of hook and straight steel fibers showed some influence on the physical and mechanical properties which are slump, density, water absorption, compressive, and flexural strength. Overall, the changes of the slump, density, and water absorption for geopolymer concrete with reinforcement of hook and straight steel fibers were not significant and is still acceptable to be used as concrete in normal applications. However, there was a significant improvement for both types of samples in the mechanical properties especially the flexural strength which is due to the bridging effect. The addition of hook steel fibers has proven to give a higher improvement to mechanical properties compared to the addition of straight steel fibers. Overall, the types of hooked-end steel fibers are better to be used as reinforcement on Malaysian fly ash-based geopolymer concrete compared to straight steel fibers due to its better mechanical performance with acceptable physical properties. The source of alumino-silicate, which is the Malaysian fly ash, has proven to be used as a precursor in the production of steel fiber reinforced geopolymer concrete.

Author Contributions: Conceptualization and writing, M.A.F. and M.M.A.B.A.; supervision and resources, M.M.A.B.A. and R.M.; review and editing, M.F.A.H., K.B. and B.J.; methodology, N.A.M.M. and M.F.G.; validation, S.G.; formal analysis, P.P.; investigation M.A.F. and M.M.A.B.A.; resources, M.M.A.B.A.; visualization, M.A.F. and M.M.A.B.A. All authors have read and agreed to the published version of the manuscript.

Funding: This research was financially supported by Centre of Excellent Geopolymer \& Green Technology (CeGeoGTech) and the Faculty of Engineering Technology, University Malaysia Perlis.

Institutional Review Board Statement: Not applicable.

Informed Consent Statement: Not applicable. 
Data Availability Statement: The data presented in this study are available on request from the corresponding author.

Acknowledgments: The authors also would like to extend their gratitude to the Department of Physics and Faculty of Mechanical Engineering and the Computer Science, Czestochowa University of Technology, Częstochowa, Poland.

Conflicts of Interest: The authors declare no conflict of interest.

\section{References}

1. Nuaklong, P.; Sata, V.; Chindaprasirt, P. Influence of recycled aggregate on fly ash geopolymer concrete properties. J. Clean. Prod. 2016, 112, 2300-2307. [CrossRef]

2. Abdullah, M.M.A.B.; A Faris, M.; Tahir, M.F.M.; A Kadir, A.; Sandu, A.V.; Isa, N.A.A.M.; Corbu, O. Performance and Characterization of Geopolymer Concrete Reinforced with Short Steel Fiber. IOP Conf. Ser. Mater. Sci. Eng. 2017, $209,12038$. [CrossRef]

3. Wazien, A.W.; Abdullah, M.M.A.B.; Razak, R.A.; Rozainy, M.M.R.; Tahir, M.F.M.; Faris, M.A.; Hamzah, H.N. Review on Potential of Geopolymer for Concrete Repair and Rehabilitation. Matec Web Conf. 2016, 78, 01065. [CrossRef]

4. Li, O.H.; Yun-Ming, L.; Cheng-Yong, H.; Bayuaji, R.; Abdullah, M.M.A.B.; Loong, F.K.; Jin, T.A.; Teng, N.H.; Nabiałek, M.; Jeż, B.; et al. Evaluation of the Effect of Silica Fume on Amorphous Fly Ash Geopolymers Exposed to Elevated Temperature. Magnetochemistry 2021, 7, 9. [CrossRef]

5. Zailani, W.W.A.; Abdullah, M.M.A.B.; Arshad, M.F.; Razak, R.A.; Tahir, M.F.M.; Zainol, R.R.M.A.; Nabialek, M.; Sandu, A.V.; Wysłocki, J.J.; Błoch, K. Characterisation at the Bonding Zone between Fly Ash Based Geo-polymer Repair Materials (GRM) and Ordinary Portland Cement Concrete (OPCC). Materials 2021, 14, 56. [CrossRef]

6. Nor, A.M.; Yahya, Z.; Abdullah, M.M.A.B.; Razak, R.A.; Ekaputri, J.J.; Faris, M.A.; Hamzah, H.N. A Review on the Manufacturing of Lightweight Aggregates Using Industrial By-Product. Matec Web Conf. 2016, 78, 01067. [CrossRef]

7. Kamilah, N.; Fathullah, M.; Abdullah, M.M.A.; Faris, M.A.; Tahir, F.; Shayfull, Z.; Nasir, S.M.; Shazzuan, M.; Wazien, A.Z.W. Surface Integrity of Steel Fibre Reinforced Fly Ash Geopolymer in CNC Lathe Operation. In Proceedings of the Fourth Huntsville Gamma-Ray Burst Symposium, Huntsville, AL, USA, 15-20 September 1997; AIP Publishing: Melville, NY, USA, 2018; Volume 2030, p. 020065.

8. Fauziah, P.Y.; Fathullah, M.; Abdullah, M.M.A.; Faris, M.A.; Tahir, F.; Shayfull, Z.; Nasir, S.M.; Shazzuan, M.; Wazien, A.Z.W. Cutting tool wear optimization in the machining of fly ash geopolymer using Taguchi method. In Proceedings of the Fourth Huntsville Gamma-Ray Burst Symposium, Huntsville, AL, USA, 15-20 September 1997; AIP Publishing: Melville, NY, USA, 2018; Volume 2030, p. 020067.

9. Fauziah, P.Y.; Fathullah, M.; Abdullah, M.M.A.; Faris, M.A.; Tahir, F.; Shayfull, Z.; Nasir, S.M.; Lih, T.C.; Wazien, A.Z.W. A review on cutting tool wear in the machining of fly ash geopolymer. In Proceedings of the Fourth Huntsville Gamma-Ray Burst Symposium, Huntsville, AL, USA, 15-20 September 1997; AIP Publishing: New York, NY, USA, 2018; Volume 2030, p. 020066.

10. Kamilah, N.; Fathullah, M.; Abdullah, M.M.A.; Faris, M.A.; Tahir, F.; Shayfull, Z.; Nasir, S.M.; Shazzuan, M.; Wazien, A.Z.W. A review on surface integrity of steel fibre reinforced fly ash geopolymer using lathe operation. In Proceedings of the AIP Conference Proceedings 2018; AIP Publishing: New York, NY, USA, 2018; p. 020064.

11. A Hashim, M.F.; Abdullah, M.M.A.B.; Sandu, A.V.; Puskas, A.; Daud, Y.M.; Zainal, F.F.; Faris, M.A. Advanced glass reinforced epoxy filled fly ash based geopolymer filler: Preparation and characterization on piping materials. IOP Conf. Ser. Mater. Sci. Eng. 2019, 572, 012037. [CrossRef]

12. Ariffin, N.; Abdullah, M.M.A.B.; Zainol, M.R.R.M.A.; Murshed, M.F.; Zain, H.; Faris, M.A.; Bayuaji, R. Review on Adsorption of Heavy Metal in Wastewater by Using Geopolymer. Matec Web Conf. 2017, 97, 01023. [CrossRef]

13. Bindiganavile, V.; Banthia, N. Impact response of the fiber-matrix bond in concrete. Can. J. Civ. Eng. 2005, 32, 924-933. [CrossRef]

14. Kim, J.-I.; Gong, M.-H.; Song, J.-Y.; Oh, S.-K.; Kim, B. A Study of Waterproof Reinforcement Layers for the Post-Cracking Behavior of Fiber Reinforced Concrete. Appl. Sci. 2020, 10, 5762. [CrossRef]

15. Berkowski, P.; Kosior-Kazberuk, M. Effect of Fiber on the Concrete Resistance to Surface Scaling Due to Cyclic Freezing and Thawing. Procedia Eng. 2015, 111, 121-127. [CrossRef]

16. Frazão, C.M.V.; Barros, J.A.O.; Camões, A.; Alves, A.M.V.C.P.; Rocha, L. Corrosion effects on pullout behavior of hooked steel fibers in self-compacting concrete. Cem. Concr. Res. 2016, 79, 112-122. [CrossRef]

17. Qian, C.; Stroeven, P. Development of hybrid polypropylene-steel fibre-reinforced concrete. Cem. Concr. Res. 2000, 30, 63-69. [CrossRef]

18. Ranjbar, N.; Zhang, M. Fiber-reinforced geopolymer composites: A review. Cem. Concr. Compos. 2020, 107, 103498. [CrossRef]

19. Alrshoudi, F.; Mohammadhosseini, H.; Tahir, M.M.; Alyousef, R.; Alghamdi, H.; Alharbi, Y.R.; AlSaif, A. Sustainable Use of Waste Polypropylene Fibers and Palm Oil Fuel Ash in the Production of Novel Prepacked Aggregate Fiber-Reinforced Concrete. Sustainability 2020, 12, 4871. [CrossRef]

20. Zheng, X.; Zhang, J.; Wang, Z. Effect of multiple matrix cracking on crack bridging of fiber reinforced engineered cementitious composite. J. Compos. Mater. 2020, 54, 3949-3965. [CrossRef] 
21. Mohammadhosseini, H.; Tahir, M.M.; Alyousef, R.; Alabduljabbar, H. Production of sustainable concrete composites comprising waste metalized plastic fibers and palm oil fuel ash. New Mater. Civ. Eng. 2020, 435-457. [CrossRef]

22. Afroughsabet, V.; Ozbakkaloglu, T. Mechanical and durability properties of high-strength concrete containing steel and polypropylene fibers. Constr. Build. Mater. 2015, 94, 73-82. [CrossRef]

23. Wongruk, R.; Songpiriyakij, S.; Sukontasukkul, P.; Chindaprasirt, P.; Chindaprasert, P. Properties of Steel Fiber Reinforced Geopolymer. Key Eng. Mater. 2015, 659, 143-148. [CrossRef]

24. Marcalikova, Z.; Cajka, R.; Bilek, V.; Bujdos, D.; Sucharda, O. Determination of Mechanical Characteristics for Fiber-Reinforced Concrete with Straight and Hooked Fibers. Crystals 2020, 10, 545. [CrossRef]

25. Choi, W.-C.; Jung, K.-Y.; Jang, S.-J.; Yun, H.-D. The Influence of Steel Fiber Tensile Strengths and Aspect Ratios on the Fracture Properties of High-Strength Concrete. Materials 2019, 12, 2105. [CrossRef] [PubMed]

26. Afroughsabet, V.; Biolzi, L.; Ozbakkaloglu, T. Influence of double hooked-end steel fibers and slag on mechanical and durability properties of high performance recycled aggregate concrete. Compos. Struct. 2017, 181, 273-284. [CrossRef]

27. ASTM C 143/C 143M-98. Standard Test Method for Slump of Hydraulic, Cement Concrete; ASTM: West Conshohocken, PA, USA, 1998.

28. British Standard. Method for Determination of Compressive Strength of Concrete Cubes BS 1881-116; BSI: London, UK, 1983.

29. ASTM C 1018-97. Standard Test Method for Flexural Toughness and First Crack Strength of Fiber-Reinforced Concrete (Using Beam with Third-Point Loading) American Society of Testing and Materials; ASTM: West Conshohocken, PA, USA, 1998; Volume 4, pp. 506-513.

30. ASTM C618-19. Standard Specification for Coal Fly Ash and Raw or Calcined Natural Pozzolan for Use in Concrete; ASTM International: West Conshohocken, PA, USA, 2019.

31. Harshavardhan, C.; Bala Murugan, S. Study on High-Density Concrete Reinforced with Steel Fiber at Elevated Temperatures. Arpn J. Eng. Appl. Sci. 2016, 11, 11415-11420. 